\title{
Oral Cobalamin (Vitamin B12) Therapy: From Empiricism and Personal Experience to Evidence Based Medicine and Perspective of Recommendations and Guideline
}

Emmanuel Andrès*

Department of Internal Medicine, Diabetes and Metabolic Diseases, Hôpitaux Universitaires de Strasbourg, Strasbourg, France

Keywords: Vitamin B12; Cobalamin; Pernicious anemia; Foodcobalamin malabsorption; Treatment; Oral cobalamin therapy

In most countries, the classic treatment for cobalamin deficiency is based on parenteral administration - as intramuscular injections - in the form of cyanocobalamin and, more rarely, hydroxyl- or methylcobalamin [1]. In USA and UK, doses ranging from 100 to 1,000 $\mu \mathrm{g}$ per month (or every 2-3 months when hydroxocobalamin is given) are used for the duration of the patient's life [2]. In France, treatment involves the administration of $1,000 \mu \mathrm{g}$ of cyanocobalamin per day for 1 week, followed by $1,000 \mu \mathrm{g}$ per week for $1 \mathrm{month}$, followed by $1,000 \mu \mathrm{g}$ per month, again, normally for the remainder of the patient's lifetime [3].

However, cobalamin is absorbed by intrinsic factor-independent passive diffusion and daily high-dose (pharmacological dose, of at least $1,000 \mu \mathrm{g}$ per day) oral vitamin B12 can cure cobalamin deficiency, and may also induce and maintain remission in patients with megaloblastic anemia [4]. In Sweden, curative oral cobalamin treatment accounts for more than $70 \%$ of the total vitamin B12 prescribed in Sweden in 2000 [5]. The rational of this route of administration is avoiding the discomfort, inconvenience and cost of monthly injections of vitamin B12 [6].

Until recent years, prescription of oral cobalamin therapy is primarily based on the knowledge and belief of each practitioner, on empirical data, and in clinical practice, on personal experience [7]. To our knowledge, this modality of vitamin B12 prescription is not taught in most countries in medical schools, absent from the majority of medical textbooks and no international recommendations or guidelines are available.

In 2002, a review by Lane et al. has reported data on the efficacy of oral vitamin B12 treatment and gives to the clinician a few keys on the prescription modality [4]. Since this date, several studies that fulfilled the criteria of evidence based-medicine were published on the efficacy of oral cobalamin therapy [6].

Two prospective randomized controlled studies comparing oral vitamin $\mathrm{B} 12$ versus intramuscular vitamin $\mathrm{B} 12$ treatment documented the efficacy of oral vitamin B12 as a curative treatment $[8,9]$. Kuzminski et al. [8] in a prospective randomized trial including 38 patients, reported improvement of hematological parameters and vitamin B12 levels (mean value: $907 \mathrm{pg} / \mathrm{mL}$ ), after 4 months of oral cyanocobalamin therapy using a higher dose of cobalamin (i.e. $2000 \mu \mathrm{g}$ per day).

Bolaman et al. [9] in a prospective randomized trial of 60 patients, also reported significant improvement of hematological parameters and vitamin B12 levels (mean improvement: $+140.9 \mathrm{pg} / \mathrm{mL}$ ), after 3 months of daily $1000 \mu \mathrm{g}$ of oral cyanocobalamin therapy

An evidence-based analysis by the Vitamin B12 Cochrane Group supports the efficacy of oral vitamin B12 as a curative treatment, with a dose between 1,000 and 2,000 $\mu$ g initially prescribed daily and then weekly [10]. In this analysis, serum vitamin B12 levels increased significantly in patients receiving oral vitamin B12 and both groups of patients (receiving oral and intramuscular treatment) showed an improvement in neurological symptoms. The Cochrane Group concludes that daily oral therapy "may be as effective as intramuscular administration in obtaining short term hematological and neurological responses in vitamin B12 deficient patients" [10].

In a randomized, parallel-group, double-blind, dose-finding trial, Eussen et al. [11] showed that the lowest dose of oral cyanocobalamin required to normalize mild cobalamin deficiency is more than 200 times the recommended dietary allowance of approximately $3 \mu \mathrm{g}$ daily (i.e. $>500 \mu \mathrm{g}$ per day).

Our working group (CARE B12, Hôpitaux Universitaires de Strasbourg, Strasbourg, France) has developed an effective oral curative treatment in patients presenting with Food-Cobalamin Malabsorption (FCM) and Pernicious Anemia (PA) using crystalline cyanocobalamin [6].

In a first study, we prospectively studied 10 patients with cobalamin deficiency and well-established FCM who received 3000 or $5000 \mu \mathrm{g}$ of oral crystalline cyanocobalamin once a week for at least 3 months [12]. After 3 months of treatment, all patients had increased hemoglobin levels (mean increase of $1.9 \mathrm{~g} / \mathrm{dL}$; $95 \%$ confidence interval: 0.9 to $3.9 \mathrm{~g} /$ $\mathrm{dL} ; \mathrm{p}<0.01$ compared with baseline), and decreased mean erythrocyte cell volume (mean decrease of $7.8 \mathrm{fL}$; $95 \%$ confidence interval: 0.9 to $16.5 \mathrm{fL} ; \mathrm{p}<0.001)$. However, 2 patients had only minor, if any, responses. Serum cobalamin levels were increased in all 8 patients in whom it was measured.

We also studied in an open study 10 patients with well-documented cobalamin deficiency related to PA who daily received $1000 \mu \mathrm{g}$ of oral crystalline cyanocobalamin for at least 3 months [13]. After 3 months of treatment, serum cobalamin levels were increased in all 9 patients in whom it was measured (mean increase of $117.4 \mathrm{pg} / \mathrm{mL} ; \mathrm{p}<0.0001$ compared with baseline). Eight patients had increased hemoglobin levels (mean increase of $2.45 \mathrm{~g} / \mathrm{dL} ; \mathrm{p}<0.01$ ). All 10 patients had decreased mean erythrocyte cell volume (mean decrease of $10.4 \mathrm{fL} ; \mathrm{p}$ $<0.003)$. Three patients experienced clinical improvements.

*Corresponding author: Prof. E. Andrès, Service de Médecine Interne, Diabète et Maladies Métaboliques, Clinique Médicale B, Hôpital Civil - Hôpitaux Universitaires de Strasbourg, 1 porte de l'Hôpital, 67091 Strasbourg Cedex, France, Tel: 3-33-8811-50-66; Fax: 3-33-88-11-62-62; E-mail: emmanuel.andres@chru-strasbourg.fr

Received April 20, 2012; Accepted April 21, 2012; Published April 27, 2012

Citation: Andrès E (2012) Oral Cobalamin (Vitamin B12) Therapy: From Empiricism and Personal Experience to Evidence Based Medicine and Perspective of Recommendations and Guideline. J Blood Disord Transfus 3:e102. doi:10.4172/2155-9864.1000e102

Copyright: (C) 2012 Andrès E. This is an open-access article distributed under the terms of the Creative Commons Attribution License, which permits unrestricted use, distribution, and reproduction in any medium, provided the original author and source are credited. 
Citation: Andrès E (2012) Oral Cobalamin (Vitamin B12) Therapy: From Empiricism and Personal Experience to Evidence Based Medicine and Perspective of Recommendations and Guideline. J Blood Disord Transfus 3:e102. doi:10.4172/2155-9864.1000e102

Page 2 of 2

Analysis of several other studies (open, not randomized) we have conducted of this topic show that all of patients who were treated orally corrected their vitamin B12 levels and at least two-thirds corrected their hematological abnormalities [14-16]. Moreover, one-third of patients experienced a clinical improvement on oral treatment. In most cases of FCM a "low" cobalamin dose (i.e. $125-1,000 \mu \mathrm{g}$ of oral crystalline cyanocobalamin per day) was used.

Since the 1990's, at least half of these patients with vitamin B12 deficiency were treated with oral cyanocobalamin, with a dose between 125 and 2,000 $\mu \mathrm{g}$ per day. All of the patients who were treated orally corrected their vitamin B12 levels and at least $80 \%$ corrected their hematological abnormalities. Moreover, half of the patients experienced a clinical improvement on oral treatment.

Thus, we currently recommend a dose of $1,000 \mu \mathrm{g}$ per day of oral cyanocobalamin, for life, in case of PA. We recommend 1,000 $\mu \mathrm{g}$ per day of oral cyanocobalamin for 1 month and than 125 to $1,000 \mu \mathrm{g}$ per day in case of intake vitamin B12 deficiency or FCM [6]. It is to keep in mind that the effect of oral cobalamin treatment in patients presenting with severe neurological manifestations has not yet been adequately documented, both in our experience that in the literature.

In conclusion, we believe that data on the efficacy of vitamin B12 administered orally are numerous enough to propose international consensual recommendations and guideline.

\section{References}

1. Carmel R (2000) Current concepts in cobalamin deficiency. Annu Rev Med 51: $357-375$

2. Lee GR (1999) Pernicious anemia and other causes of vitamin B12 (cobalamin) deficiency. (10thedn), Williams \& Wilkins, Baltimore.

3. Zittoun J (1996) Cobalamines: actualisation des données métaboliques, cliniques, diagnostiques et thérapeutiques. Hématologie 58: 332-337.

4. Lane LA, Rojas-Fernandez C (2002) Treatment of vitamin B12 deficiency anemia: oral versus parenteral therapy. Ann Pharmacother 36: 1268-1272.
5. Nyholm E, Turpin P, Swain D, Cunningham B, Daly S, et al. (2003) Oral vitamin B12 can change our practice. Postgrad Med J 79: 218-220.

6. Andrès E, Fothergill H, Mecili M (2010) Efficacy of oral cobalamin (vitamin B12) therapy. Expert Opin Pharmacother 11: 249-256.

7. Graham ID, Jette N, Tetroe J, Robinson N, Milne S, et al. (2007) Oral cobalamin remains medicine's best kept secret. Arch Gerontol Geriatr 44: 49-59.

8. Kuzminski AM, Del Giacco EJ, Allen RH, Stabler SP, Lindenbaum J (1998) Effective treatment of cobalamin deficiency with oral cobalamin. Blood 92: 1191-1198.

9. Bolaman Z, Kadikoylu G, Yukselen V, Yavasoglu I, Barutca S, et al. (2003) Ora versus intramuscular cobalamin treatment in megaloblastic anemia: a singlecenter, prospective, randomized, open-label study. Clin Ther 25: 3124-3134.

10. Vidal-Alaball J, Butler CC, Cannings-John R, Goringe A, Hood K, et al. (2005) Oral vitamin B12 versus intramuscular vitamin B12 for vitamin B12 deficiency. Cochrane Database Syst Rev 20: CD004655.

11. Eussen SJ, de Groot LC, Clarke R, Schneede J, Ueland PM, et al. (2005) Ora cyanocobalamin supplementation in older people with vitamin B12 deficiency: a dose-finding trial. Arch Intern Med 165: 1167-1172.

12. Andrès E, Kurtz JE, Perrin AE, Maloisel F, Demangeat C, et al. (2001) Oral cobalamin therapy for the treatment of patients with food-cobalamin malabsorption. Am J Med 111: 126-129.

13. Andrès E, Loukili NH, Noel E, Maloisel F, Vinzio S, et al. (2005) Oral cobalamin (daily dose of $1000 \mu \mathrm{g}$ ) therapy for the treatment of patients with pernicious anemia. An open label study of 10 patients. Curr Ther Research 66: 13-22.

14. Andrès E, Kaltenbach G, Noel E, Noblet-Dick M, Perrin AE, et al. (2003) Efficacy of short-term oral cobalamin therapy for the treatment of cobalamin deficiencies related to food-cobalamin malabsorption. A study of 30 patients. Clin Lab Haematol 25: 161-166.

15. Kaltenbach G, Noblet-Dick M, Andrès E, Barnier-Figue G, Noel E, et al. (2003) Early response to oral cobalamin therapy in older patients with vitamin B12 deficiency. Ann Med Interne (Paris) 154: 91-95.

16. Andrès E, Kaltenbach G, Noblet-Dick M, Noel E, Vinzio S, et al. (2006) Hematological response to short-term oral cyanocobalamin therapy for the treatment of cobalamin deficiencies in elderly patients. J Nutr Health Aging 10: $3-6$. 